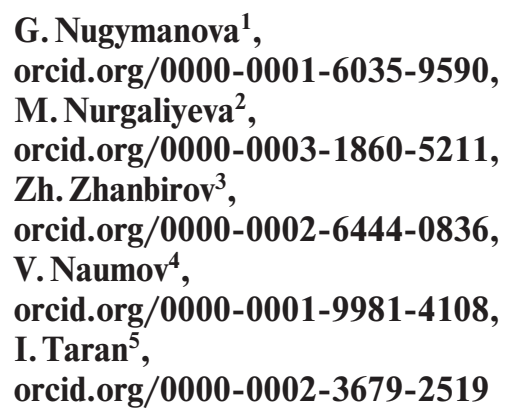

1 - Kazakh Academy of Transport and Communications, Almaty, Republic of Kazakhstan

2 - Kazakh Automobile and Road L. Goncharov Academy, Almaty, Republic of Kazakhstan

3 - Central Asian University, Almaty, Republic of Kazakhstan 4 - Cracow University of Technology, Krakow, Poland

5 - Dnipro University of Technology, Dnipro, Ukraine, e-mail: taran7077@gmail.com

\title{
CHOOSING A SERVICING COMPANY'S STRATEGY WHILE INTERACTING WITH FREIGHT OWNERS AT THE ROAD TRANSPORT MARKET
}

Purpose. To develop the methodology for choosing the strategies of freight forwarding companies in the situation of interaction with freight owners as customers of forwarding services.

Methodology. The game-theoretical approach is used to formalize the conflict situation between a freight forwarding company and a cargo owner. A set of services proposed by forwarders is used as the base in order to represent possible strategies of a forwarder as the vector of probabilities that the respective services are provided for a client. The strategies of the cargo owner are represented as a binary variable that shows whether the client uses the provided services or not. The payoff function for a forwarder is defined as the company's profit and the client's payoff function - as fee paid for forwarding services. To determine the influence of the demand parameters on the forwarder's optimal strategies, the demand for transport services is represented as a flow of requests characterized by two numeric parameters - delivery distance and consignment weight.

Findings. The conducted experimental studies have shown that as a result of the use of the proposed methodology, the optimal strategy of a forwarding company can always be determined from the payoff matrix. The performed simulation experiment allowed us to state that in most cases the forwarder's optimal strategy is mixed (the technological and commercial services should be provided with the given probability while servicing the flow of requests from freight owners).

Originality. The studies on the influence of the request flow parameters on the probabilities of choosing the elementary strategies are carried in the paper for the first time.

Practical value. The proposed methodology can be used as the basic tool for supporting decisions of freight forwarders while servicing the cargo owners at the market of road freight transportation.

Keywords: freight forwarding, game-theoretical approach, transport demand parameters, flow of requests

Introduction. Freight forwarding operations are the necessary element in the structure of the contemporary supply chains, not depending on the type of goods being delivered, but especially efficient the forwarding services are in mass deliveries - in transportation of goods for metallurgical and mining industry.

The activities of modern freight forwarding companies (FFC) have mostly the intermediary character and therefore are characterized by the presence of conflict situations arising from the need to coordinate the interests of various entities participating in the transportation processes.

The correct organization of the forwarding service process involves:

- reduction of excess time spent on idle time of vehicles for loading and unloading goods due to: expanding the areas dedicated to loading and unloading operations and the use of their complex mechanization; drawing up and strictly adhering to schedules for the delivery and operation of vehicles and mechanisms; creation of driveways and areas for maneuvering of vehicles, especially for vehicles with trailers; preliminary preparation of goods, and so on;

- correct placement of loads in the vehicle's body that contributes to the even distribution of the weight load on the chassis of the vehicle and, as a consequence, to facilitating of its driving;

- optimal modes of movement of vehicles on the relevant sections of the delivery route, taking into account the state of the road surface, visibility, traffic intensity, and other factors, with strict observance of the rules of the road traffic, as well as the knowledge by the drivers of the main technical character-

(C) Nugymanova G., Nurgaliyeva M., Zhanbirov Zh., Naumov V., Taran I., 2021 istics and operating rules, various brands of rolling stock of road transport when transporting the corresponding goods;

- transportation of goods should be carried out along rationally constructed routes, taking into account the shortest distances, regimes of movement on each section of the delivery route, with preferably ensuring the loading of cars in both directions;

- rational stowage of goods, the use of removable boards at vehicles while delivering, and so on, allowing the maximum use of the carrying capacity of the rolling stock;

- maximum use of the drivers' working time within the framework of the legislation, due to the consolidation of the operating mode of vehicles by organizing the brigade work method.

The main tasks of freight forwarders while arranging the transportation of goods are usually the following:

- providing a high level of customer service;

- implementation of existing transportation plans;

- the full satisfaction of customers' needs in road transport;

- efficient use of vehicles that increases labor productivity, and minimizes transportation costs;

- and systematic profit-making.

The transportation system managed by forwarding companies should provide:

- coordination of the work of all departments and employees of a FFC;

- optimal organization of the transport process;

- efficient use of the rolling stock of vehicles;

- the profitability of transportation;

- delivery of goods in the shortest possible time.

Freight forwarding processes are highly stochastic that is determined by random parameters of demand for forwarding services and the uncertainty of the numeric parameters characterizing the process of transportation. 
Based on the content and features of the processes of freight forwarding services, we can conclude that it is advisable to use the apparatus of the game theory to select the optimal strategies of freight forwarders at the market of transport services. The authors considered the problems of organizing transportation in Kazakhstan in the works [1,2].

Literature review. A game-theoretical approach is quite a popular methodology used in numerous studies in the area of transportation. In the recent publications, this approach was used for solving the routing problem with time windows [3] and defining time windows for transport servicing operations [4], substantiating the price for transport services [5-7], allocating the greenhouse gas emissions to shipments [8], increasing the reliability of transportation systems [9], sharing the profits between transport companies [10, 11], substantiating the most efficient mode of transport or the combination of the modes in the intermodal transportation system [12], enhancing port-hinterland container transportation network resilience [13], and others.

The methodology of game theory is applied for solving transportation-related problems for various modes of transport: railway transport [5, 12], road transport [14], civil aviation [11], and maritime transport [9, 15]. Evolutionary game analysis on the implementation of subsidy policy for sustainable transportation development is studied [16]. As for the spatial scale of the problem being solved in the field of transport, the game-theoretical approach is widely used at the regional level $[4,17,18]$ and at the macro-scale level of the transport market as a whole [7, 19].

Solutions for conflict situations arising between business entities in the environment of the transport market are usually obtained by means of linear algebra. But in more complicated game models, which consider non-linear objective functions, more advanced mathematical apparatus is used.

The authors of the model [3] propose a multi-objective genetic algorithm in order to solve the vehicle routing problem with time windows where the additional risks are estimated based on the game-theoretical approach. A hybrid genetic algorithm is also developed by the authors of the paper [12] for the purposes of designing the collaborative transport network for deliveries of the oil and gas drilling equipment. The evolutionary multi-objective algorithm was applied as well in the paper [17]: the authors propose to use it as the main tool in order to solve the planning problems of a merchandise distribution firm that dispatches small volume fractional loads of fresh foods in a city.

Another additional tool used in the game-theoretical models at transport is the fuzzy sets theory. In the paper [7], its author proposes an agent-based model of a freight transport market where the decision-making process of individual agents is simulated through a normative stepwise approach using the fuzzy set theory and accumulated market knowledge. The authors of the paper [19] use the fuzzy sets in order to identify and evaluate quantitatively the indicators of sustainability risks for the freight transportation systems.

The crucial element of the game model is the payoff function describing the outcome of the conflict situation being considered. The most commonly used indicator for the payoff function in the transportation-related game-theoretical models is the expenses of the entities involved in a conflict situation $[3,9,12]$, but also other criteria are defined in the recent publications, such as profit of a business entity $[10,18]$ or prices of the transport services $[5,7]$.

In the papers [6] and [14], the strategies of the players at the market are determined using the rate of return, an indicator that shows which part of the cost of service constitutes profit.

In the publication [14] it is shown that the payoff functions of the transportation market participants can be defined in the following way

$$
\left[\begin{array}{l}
H_{F F}=\left[S_{F F}+S_{C} \cdot\left(1+R_{C}\right)\right] \cdot R_{F F} \\
H_{F O}=T-\left[S_{F F}+S_{C} \cdot\left(1+R_{C}\right)\right] \cdot\left(1+R_{F F}\right) \\
H_{C}=S_{C} \cdot R_{C}
\end{array},\right.
$$

where $H_{F F}, H_{F O}$ and $H_{C}$ are payoff functions of a forwarder, a freight owner and a carrier respectively; $S_{F F}$ and $S_{C}$ are costs of the forwarder's and the carrier's services respectively; $R_{F F}$ and $R_{C}$ are rates of return for a forwarding company and a carrier respectively; $T$ is the service price at the freight transportation market.

It was determined that for a conflict between the FFC and the cargo owner when setting a service fee, the best strategies for market participants could be evaluated by dependencies

$$
\left[\begin{array}{l}
R_{F F}^{*}=\frac{T-S_{F F}-S_{C} \cdot\left(1+R_{C}\right)}{2 \cdot\left[S_{F F}+S_{C} \cdot\left(1+R_{C}\right)\right]} \\
\delta^{*}=0.5 \cdot\left[S_{F F}+S_{C} \cdot\left(1+R_{C}\right)-T\right]
\end{array},\right.
$$

where $R_{F F}^{*}$ is the optimal value of the profitability rate set by the freight forwarder at the price for its services; $\delta^{*}$ is the optimal strategy of the freight owner (the difference between the average market price of the services and the price paid by the cargo owner).

For the conflict situation between a forwarding company and a carrier when establishing the fee for the delivery service, the optimal strategies of the players (appropriate profitability rates $R_{C}^{*}$ and $R_{F F}^{*}$ ) are evaluated in the following way

$$
\left[\begin{array}{l}
R_{C}^{*}=\frac{T_{\delta}-S_{F F}-S_{C}}{2 \cdot S_{C}} \\
R_{F F}^{*}=\frac{T_{\delta}-S_{F F}-S_{C}}{T_{\delta}+S_{F F}+S_{C}}
\end{array},\right.
$$

where $T_{\delta}$ is the service fee that was established by a carrier for a freight owner.

This approach allows determining the optimal strategies of the entities of the freight transportation market analytically; however, it makes it possible to assess only the price component of the strategies of forwarders and carriers in the considered conflict situations.

Unsolved aspects of the problem. The analysis of approaches to improving the efficiency of the freight forwarding processes allows us to highlight the following disadvantages: most of the approaches are aimed at increasing the competitiveness of the forwarding operations, but they do not directly take into account the presence of competition in the market of transport services; in addition, the existing approaches are aimed at solving particular problems and are characterized by the absence of an integrated approach.

In this paper, we contribute to the direction of finding the optimal strategies for entities of the freight transportation market. We aim to fill the gap in the existing methodology for the substantiation of the FFC strategies in the conflict situation of the forwarder's interaction with freight owners (or third-party companies that represent the cargo owner).

Purpose. The goal of the study is to develop a methodology for determining the optimal strategy for the behavior of forwarding companies in the environment of the transportation services market.

The object of the research is the process of FFS of enterprises and organizations, and the subject is the conflict situation between the forwarder and the customer of the service (freight owner). The conflict between these parties can be described in the following way: the forwarder seeks to provide services to the client with the greatest possible profit, that is, at the highest possible rate for the services provided; on the other hand, the client (cargo owner) seeks to reduce the costs for the received forwarding and transportation services. 
To achieve the goal of the study, we identify possible strategies of the forwarder and the cargo owner in a conflict situation, formalize the payoff functions of the transport process participants, and use the methods of game theory to determine optimal strategies. Additionally, in order to assess the influence of demand parameters on the probabilities of the strategies' choice, a simulation experiment is carried out.

Simulating the conflict situation. In accordance with [18], a conflict situation is formalized as the game in the following way

$$
\Gamma=\left\langle I,\left\{r_{i}\right\}_{i \in I},\left\{H_{i}\right\}_{i \in I}\right\rangle,
$$

where $I$ is the set of players; $r_{i}$ is the set of available strategies of the $i^{\text {th }}$ player; $H_{i}$ is the payoff function describing the game outcome for the $i^{\text {th }}$ player.

In the paper [14], the main types of conflict situations arising in the process of freight forwarding services (FFC) functioning in the freight transportation market are highlighted: the conflict between the freight forwarder and the carrier in setting the payment for transportation and the conflict between the forwarding company and the freight owner when setting the payment for the services to be provided.

For the first case, the set $I$ consists of two elements: $I_{1}=$ $=\{F F, C\}$, where $F F$ is a forwarding company, and $C$ is a road transport carrier. For the case of a conflict between an FFC and a cargo owner $I_{2}=\{F F, F O\}$, where $F O$ is the customer of freight forwarding services (cargo owner). In addition, we can consider the conflict for the three specified players, in such situation the set of players $I_{3}=\{F F, C, F O\}$.

A player's strategy is a set of rules that determine the choice of its activities for each personal action (move), depending on the current situation. Usually, during the game, at each personal move, the player makes a choice depending on the specific situation. However, it is possible that all decisions are made by the player in advance (in response to any situation that may arise). This means that the player has chosen a certain strategy, which can be set in the form of a list of rules or a defined program of actions.

To formalize the strategies of participants in the considered conflict situation, it is necessary to determine the elementary actions of the forwarder and the cargo owner when interacting at the freight transportation market. The elementary actions of an FFC in the aggregated form include services $A_{k}(k=1 \ldots 5)$ provided by forwarding companies: $A_{1}-$ provision of technological services (processing and storage, reception and delivery of cargo, paperwork, transportation of goods); $A_{2}$ - provision of information and reference services (provision of consulting services; providing information on the movement of goods; informing about the recent state of the transport market including available services and current tariffs; information on the availability of cargo at loading points); $A_{3}$ - provision of commercial services (performing calculations; accounting and reporting; providing the insurance of cargo and vehicles; selling the containers or package materials to the client; leasing of additional equipment); $A_{4}$ - provision of related services (booking and providing rooms in hotels; providing visa support; catering and recreation for drivers and forwarders; organization of a guarded parking lot for rolling stock; medical support of drivers and forwarders; maintenance and refueling of vehicles); $A_{5}$ - provision of organizational services (selection of the optimal route; selection of a rational type of transport; synchronization of the work of loading and unloading points and carriers).

Combinations of different conjunctions of $A_{k}$ represent the forwarding strategies. In accordance with the terminology of game theory [20], the set of all combinations of elements $A_{k}$ is a set $r_{F F}$ of a freight forwarder's strategies. In this case, the element of the set of all admissible strategies can be conveniently represented as a vector $\Phi_{A} \in r_{F F}$

$$
\Phi_{\grave{A}}=\left|\begin{array}{ccc}
A_{1} & \ldots & A_{S} \\
\varphi_{1} & \ldots & \varphi_{S}
\end{array}\right|,
$$

where $\varphi_{1}, \ldots, \varphi_{S}$ are the probabilities that the services are provided by a forwarding company, $\sum_{k=1}^{S} \varphi_{k}=1 ; S$ is the number of
all possible servicing actions.

For conditions of competition in the transport services market, the elementary actions of the cargo owner are the use of services $\left(B_{1}\right)$ or refusal to being serviced by a specific $\mathrm{FFC}\left(B_{2}\right)$.

As a payoff function of the forwarding company as a subject of entrepreneurial activity, it is expedient to determine the profit from servicing a specific request from the freight owner

$$
P_{F F}=D_{F F}-E_{F F},
$$

where $P_{F F}$ is the freight forwarder's profit, EUR/request; $D_{F F}$ is the forwarder's income, EUR/request; $E_{F F}$ is the forwarding company's expenses, EUR/request

$$
D_{F F}=\sum_{k=1}^{S} T_{k},
$$

where $T_{k}$ is the tariff for the $k^{\text {th }}$ service, EUR/request; $\sum_{k=1}^{S} T_{k}$ is the total amount of paid services of a FFC, EUR/request;

$$
E_{F F}=E_{D S}+E_{U}+E_{R}+E_{C S},
$$

where $E_{D S}$ is dispatchers' salary costs, EUR/request; $E_{U}$ is the cost of paying utility bills, EUR/request; $E_{R}$ is the cost of renting an office space, EUR/request; $E_{C S}$ is expenses for communication services (telephone communication, Internet services, mobile communication), EUR/request

$$
E_{D S}=D_{F F} \cdot \delta_{D S},
$$

where $\delta_{D S}$ is the share of the cost of the dispatcher's salary (depends on the specific forwarding company, on average $\delta_{D S} \approx 0.1$ ).

It is obvious that for the forwarder the optimal value of the payoff function (1) will be its possible maximum.

The payoff function for a customer (cargo owner) is defined as its cost $E_{F O}$ to meet the need for FFS and has the following form

$$
E_{F O}=E_{F S}+E_{S},
$$

where $E_{F S}$ is the fee for the received forwarding services, EUR/ request; $E_{S}$ is the cost of finding the best service option, EUR/ request

$$
E_{F S}=\sum_{k=1}^{S} T_{k} .
$$

The amount of costs for finding the optimal service option can be taken in aggregate as a value that linearly depends on the payment for the forwarder's services (establishing a correlation between $E_{F S}$ and $E_{S}$, as well as the type of that dependence, is the area of future research)

$$
E_{S}=E_{F S} \cdot \delta_{S},
$$

where $\delta_{S}$ is the share of costs for the search for forwarding services that depends on the total cost of FFS (on average at the market $\delta_{D S} \approx 0.1$ ).

The optimal outcome for the freight owner in this situation is the minimum possible value of the payoff function (2).

We propose to define the integral (resulting) payoff function $H$ as the difference between the payoff functions of the forwarding company and the freight owner since the maximization of the payoff function presented in such a way satisfies both players participating in the conflict situation

$$
H=P_{F F}-E_{F O} .
$$

In the case when $D_{F F} \gg E_{F F}$ (and such ratio is typical for all forwarding companies without their own rolling stock and storage facilities), the payoff function (3) takes the following form

$$
H \approx D_{F F}-E_{F O} \text {. }
$$




$$
H \approx-\delta_{S} \cdot \sum_{k=1}^{S} T_{k}
$$

Considering the influence of the parameters of the freight owner's request for FFS on the integral payment function, it should be noted that function (5) depends on the delivery distance $L$ and the weight of the consignment $Q$

$$
H=f(Q, L) .
$$

Since the tariffs for services $A_{2}-A_{5}$ do not depend on $L$ and $Q$, we can say that $T_{2,3,4,5}=$ const in the sense of (6). The services of a technological nature $A_{1}$ include transportation, loading, and unloading operations, the amount of payment for which is determined by the parameters $L$ and $Q$.

In order to solve a game, or find a solution to a game, one should choose a strategy for each player that satisfies the optimality condition, i.e. one of the players should receive the maximum payoff when the other adheres to his strategy. At the same time, the second player should have a minimum loss if the first one sticks to their strategy. Such strategies are called optimal. Optimal strategies should also satisfy the stability condition, that is, they should be unprofitable for any of the players to abandon their strategy in this game.

When solving an arbitrary end game, it is recommended to adhere to the following scheme:

1. Eliminate clearly disadvantageous strategies from the payment matrix when compared to other strategies. Such strategies for the first player are those that correspond to rows of the payoff matrix with elements that are clearly less than elements of other rows. For the second player, disadvantageous strategies correspond to columns that are greater than elements in other columns.

2. Determine the high and low prices of the game and check if the game has a saddle point. If there is a saddle point, then the strategies of the players corresponding to it will be optimal, and the price will coincide with the upper (lower) price.

3. If there is no saddle point, then the solution should be sought in mixed strategies. For games that are characterized by more than 2 strategies for each of the players, the simplex method is recommended, for games where at least one of the players has just 2 strategies, a geometric solution is possible.

In practice, the implementation of the optimal solution in mixed strategies can be implemented in several ways. The essence of the most frequently used approach is to mix pure strategies in proportions defined by probabilities of their use.

Results of experimental studies. To solve the problem of determining the optimal behavior strategy of the parties at the conflict between the forwarder and the freight owner, it is necessary to determine the sequence of actions that can be used to obtain the optimal behavior strategy for the given entity.

We have developed the algorithm presented by the following sequence of actions:

1. Calculation of the payment function for the parties to the conflict, taking into account the use of certain strategies.

2. Drawing up an interim payment matrix.

3. Calculation of the integral payment function for the parties to the conflict.

4. Drawing up the resulting (integral) payment matrix.

5. Checking the resulting payment matrix for the presence of a saddle point in it.

6. Justification of the saddle point (if it is present in the payment matrix).

7. Evaluation of the probabilities of using their strategies by the parties to the conflict by drawing up a system of linear equations based on the resulting payment matrix.

8. Determination of optimal strategies for the forwarder and the client, taking into account the found probabilities.

Experimental studies were carried out based on the transport and production enterprise Ak-Orda-Kepil that operates at the transport market of the Republic of Kazakhstan. Taking into account the company's tariffs and average market indicators for the average values of the shipment lot and the delivery distance within the enterprise, a payment matrix was compiled. The intermediary and the resulting payoff matrices obtained based on the expression (4) are presented in Table 1 and in Table 2 respectively (the payoff function values are converted to EUR from Kazakhstani tenge - the national currency of Kazakhstan).

The bottom row of Table 1 shows the maximum payoffs of the cargo owner, and the last column shows the minimum payoffs of the forwarder. The resulting payoff matrix contains a saddle cell that corresponds to the strategy $A_{1}$ for the forwarding company (technological services) and the strategy $B_{1}$ for the freight owner (accept servicing). This indicates the presence of a pure forwarder's strategy - the provision of exclusively technological services from the considered list of the actions. However, this solution is true only for the case when all requests from clients will be characterized by the same weight of the consignment and delivery distance.

To determine the influence of demand parameters on the choice of the forwarder's strategies, a simulation experiment was carried out, during which the values of the request flow parameters $L$ and $Q$ were generated using MS Excel tools (a normal distribution law was adopted, the scale and location parameters were determined based on the results of studying the flow of requests for services of the Ak-Orda-Kepil company). Determination of optimal strategies was carried out using a linear programming apparatus; the MatLab tools (in-built solve function) were used in order to solve systems of linear equations.

The calculation results showed that for all series of the experiment the mixed strategy of the forwarder is the optimal solution, providing for the use of strategies $A_{1}$ and $A_{3}$, i. e.

$$
\left[\begin{array}{l}
\varphi_{2}=\varphi_{4}=\varphi_{5}=0 \\
\varphi_{1} \in(0 ; 1) \\
\varphi_{3} \in(0 ; 1) \\
\varphi_{1}+\varphi_{3}=1
\end{array} .\right.
$$

\begin{tabular}{|c|c|c|}
\hline Strategies & $B_{1}$ & $B_{2}$ \\
\hline$A_{1}$ & $\begin{array}{l}72.0 \\
-84.0\end{array}$ & ${ }_{72.0}-4.0$ \\
\hline$A_{2}$ & $\begin{array}{l}115.5 \\
99.0\end{array}$ & ${ }_{99.0} \longrightarrow .5$ \\
\hline$A_{3}$ & ${ }_{117.0}-136.5$ & $\mathrm{C}_{117.0}$ \\
\hline$A_{4}$ & ${ }_{90.0} \longrightarrow 105.0$ & ${ }_{90.0}-5.0$ \\
\hline$A_{5}$ & $\mathrm{~S}_{81.0}-94.5$ & 8 \\
\hline
\end{tabular}

Table 1

Example of the intermediary payoff matrix

Table 2

Example of the resulting payoff matrix

\begin{tabular}{|c|c|c|c|}
\hline Strategies & $B_{1}$ & $B_{2}$ & Minimum value of $H$ \\
\hline$A_{1}$ & -12.0 & 68.0 & -12.0 \\
\hline$A_{2}$ & -16.5 & 93.5 & -16.5 \\
\hline$A_{3}$ & -19.5 & 110.5 & -19.5 \\
\hline$A_{4}$ & -15.0 & 85.0 & -15.0 \\
\hline$A_{5}$ & -13.5 & 76.5 & -13.5 \\
\hline Maximum value of $H$ & -12.0 & 110.5 & -12.0 \\
\hline
\end{tabular}


The obtained probabilities of using strategies from the numeric parameters of the flow of requests for FFS are shown in Fig. 1 (for the consignment weight) and in Figs. 2-3 (for the delivery distance).

As can be seen from the graphs in Figs. 1-3, with an increase in the weight of the consignment and the delivery distance, the probability of using the $A_{3}$ strategy increases, and

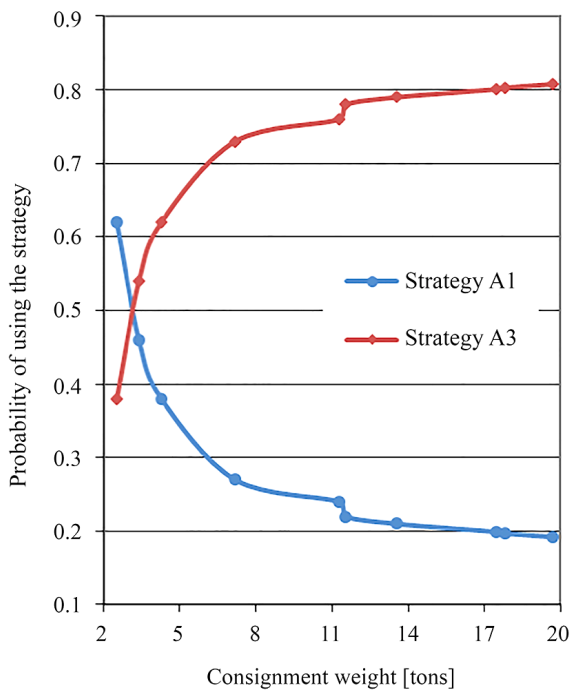

Fig. 1. Dependence of the probability of using strategies on the weight of the consignment

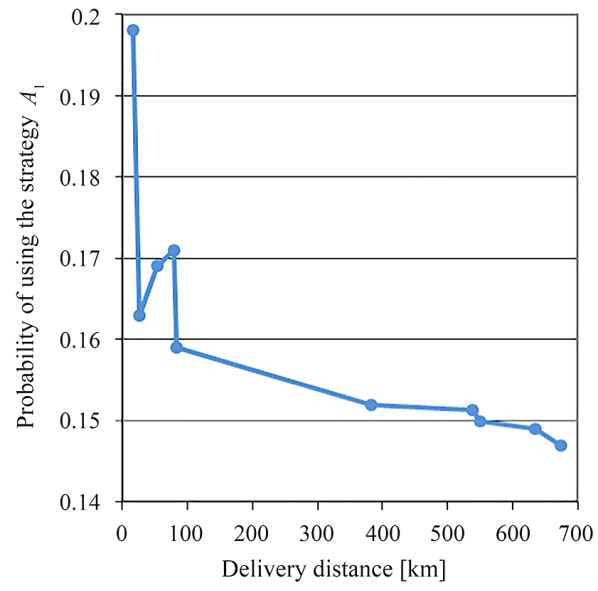

Fig. 2. Dependence of the probability of using strategy $A_{1}$ on the delivery distance

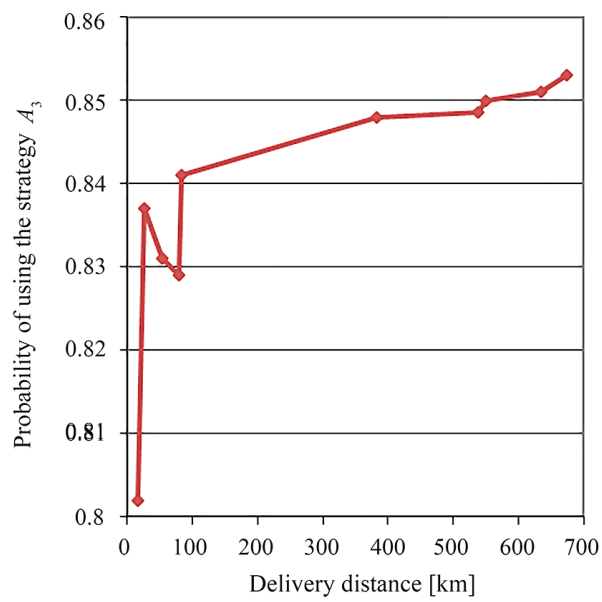

Fig. 3. Dependence of the probability of using strategy $A_{3}$ on the delivery distance the probability of using the $A_{1}$ strategy, respectively, decreases. Attention should be paid to the presence of local extrema in the delivery distance interval up to $100 \mathrm{~km}$.

Based on the results of the analysis of the simultaneous influence of demand parameters on the probability of applying strategies, it should be noted that the combination of the maximum values of the parameters leads to a decrease in the probability values, and the combination of the minimum values increases the probability of applying the $A_{1}$ strategy.

Conclusions. The performed research allowed us to indicate the advisability of providing forwarders, when servicing the clientele, mainly of such types of services as technological (processing and storage of cargo, reception, and delivery of cargo, paperwork, transportation of goods) and commercial (performing calculations, keeping records and reporting, cargo insurance, sale to the client of container or packaging, leasing equipment). Moreover, when servicing the process of delivering consignments of up to 3 tons of cargo over short distances, it will be optimal to provide mainly technological services, and when servicing large consignments of cargo over long distances (international transport), it will be the best option to provide mainly commercial services.

As a promising direction for further application of the proposed approach to determining the strategies of the forwarders when servicing cargo owners, we plan the detailing of the provided services.

\section{References.}

1. Sabraliev, N., Abzhapbarova, A., Nugymanova, G., Taran, I., \& Zhanbirov, Zh. (2019). Modern aspects of modeling of transport routes in Kazakhstan. News of the National Academy of sciences of the Republic Kazahstan, 2(434), 62-68. https://doi.org/10.32014/2019.2518-170X.39.

2. Sładkowski, A., Utegenova, A., Kolga, A. D., Gavrishev, S. E., Stolpovskikh, I., \& Taran, I. (2019). Improving the efficiency of using dump trucks under conditions of career at open mining works. Naukovyi Visnyk Natsionalnoho Hirnychoho Universytetu, (2), 36-42. https://doi.org/10.29202/nvngu/2019-2/8.

3. Ghannadpour, S. F., \& Zandiyeh, F. (2020). A new gametheoretical multi-objective evolutionary approach for cash-intransit vehicle routing problem with time windows (A Real-life Case). Applied Soft Computing Journal, (93), 106378. https:// doi.org/10.1016/j.asoc.2020.106378.

4. Eren Akyol, D., \& de Koster, R. B. M. (2018). Determining time windows in urban freight transport: A city cooperative approach. Transportation Research Part E: Logistics and Transportation Review, (118), 34-50. https://doi.org/10.1016/i. tre.2018.07.004.

5. Guo, J., Xie, Z., \& Li, Q. (2020). Stackelberg Game Model of Railway Freight Pricing Based on Option Theory. Discrete Dynamics in Nature and Society, (2020), 6436729. https://doi. org $/ 10.1155 / 2020 / 6436729$.

6. Naumov, V., \& Kholeva, O. (2017). Forming the strategies of sustainable development of freight forwarders at transportation market. Naukovyi Visnyk Natsionalnoho Hirnychoho Universytetu, (3), 129-134.

7. Reis, V. (2019). A disaggregated freight transport market model based on agents and fuzzy logic. Transportmetrica $B$, 7(1), 363-385. https://doi.org/10.1080/21680566.2017.1421108. 8. Kellner, F., \& Schneiderbauer, M. (2019). Further insights into the allocation of greenhouse gas emissions to shipments in road freight transportation: The pollution routing game. European Journal of Operational Research, 278(1), 296-313. https:// doi.org/10.1016/j.ejor.2019.04.007.

9. Asadabadi, A., \& Miller-Hooks, E. (2018). Co-opetition in enhancing global port network resiliency: A multi-leader, common-follower game theoretic approach. Transportation Research Part B: Methodological, (108), 281-298. https://doi. org/10.1016/j.trb.2018.01.004.

10. Algaba, E., Fragnelli, V., Llorca, N., \& Sánchez-Soriano, J. (2019). Horizontal cooperation in a multimodal public 
transport system: The profit allocation problem. European Journal of Operational Research, 275(2), 659-665. https://doi. org/10.1016/j.ejor.2018.11.050.

11. Luo, J., Kuang, H., Feng, T., \& Song, D. (2019). Research on the co-opetition between high speed rail and civil aviation based on two stage game model. System Engineering Theory and Practice, 39(1), 150-164. https://doi.org/10.12011/10006788-2018-0154-15.

12. Liu, D., Yan, P., Deng, Z., Wang, Y., \& Kaisar, E.I. (2020). Collaborative intermodal freight transport network design and vehicle arrangement with applications in the oil and gas drilling equipment industry. Transportmetrica $A$ : Transport Science, 16(3), 1574-1603. https://doi.org/10.1080/ 23249935.2020.1758235.

13. Chen, H., Lam, J.S.L., \& Liu, N. (2018). Strategic investment in enhancing port-hinterland container transportation network resilience: A network game theory approach. Transportation Research Part B: Methodological, (111), 83-112. https://doi.org/10.1016/j.trb.2018.03.004.

14. Naumov, V. (2012). Definition of the optimal strategies of transportation market participators. Transport Problems, 7(1), 43-52.

15. Dimitriou, L. (2021). Optimal competitive pricing in European port container terminals: A game-theoretical framework. Transportation Research Interdisciplinary Perspectives, (9), 100287. https://doi.org/10.1016/j.trip.2020.100287.

16. Zhang, L., Long, R., Huang, Z., Li, W., \& Wei, J. (2020). Evolutionary game analysis on the implementation of subsidy policy for sustainable transportation development. Journal of Cleaner Production, (267), 122159. https://doi.org/10.1016/j. jclepro.2020.122159.

17. Miguel, F., Frutos, M., Tohme, F., \& Babey, M.M. (2020). A decision support tool for urban freight transport planning based on a multi-objective evolutionary algorithm. IEEE Access, (7), 156707-156721. https://doi.org/10.1109/ ACCESS.2019.2949948.

18. Yi, Z., Xiang, C., Li, L., \& Jiang, H. (2020). Evolutionary game analysis and simulation with system dynamics for behavioral strategies of participants in crowd logistics. Transportation Letters, 1-15. https://doi.org/10.1080/19427867.2020.178 3609.

19. Shankar, R., Choudhary, D., \& Jharkharia, S. (2018). An integrated risk assessment model: A case of sustainable freight transportation systems. Transportation Research Part D: Transport and Environment, (63), 662-676. https://doi.org/10.1016/j. trd.2018.07.003.

20. Owen, G. (2013). Game Theory. Emerald Group Publishing, ISBN Print: 9781781905074, ISBN Electronic: 9781781905081.

\section{Вибір стратегії обслуговуючого підприємства при взаємодії \\ з вантажовласниками на ринку автомобільного транспорту}

\section{Г. Нугманова ${ }^{1}$, М. Нургалієва ${ }^{2}$, Ж. Жанбіров ${ }^{3}$, B. Наумов $^{4}$, I. Таран $^{5}$}

1 - Казахська Академія транспорту та комунікації імені М. Тинишпаєва, м. Алмати, Республіка Казахстан

2 - Казахська автомобільно-дорожня академія імені Л. Гончарова, м. Алмати, Республіка Казахстан

3 - Центрально-Азіатський університет, м. Алмати, Республіка Казахстан

4 - Краківський політехнічний інститут імені Т. Костюшко, м. Краків, Республіка Польща

5 - Національний технічний університет «Дніпровська політехніка», м Дніпро, Україна, e-mail: taran7077@gmail. $\underline{\mathrm{com}}$
Мета. Розробка методології вибору стратегій транспортно-експедиторських компаній у ситуації взаємодії із власниками вантажів як замовниками експедиторських послуг.

Методика. Теоретико-ігровий підхід використовується для формалізації конфліктної ситуації між транспортно-експедиторською компанією та власником вантажу. Набір послуг, запропонованих експедиторами, використовується в якості основи для представлення можливих стратегій експедитора як вектору ймовірностей надання відповідних послуг клієнту. Стратегії власника вантажу представлені у вигляді бінарної змінної, що показує, чи користатиметься клієнт наданими послугами чи нi. Функція виплат для експедитора визначається як прибуток компанії, а функція виплат клієнта - як оплата за надання експедиторських послуг. 3 метою визначення впливу параметрів попиту на оптимальні стратегії експедитора, попит на транспортні послуги представляється як потік замовлень, що характеризується двома числовими параметрами - відстанню доставки й вагою партії вантажу.

Результати. Проведені експериментальні дослідження показали, що в результаті використання запропонованої методології оптимальну стратегію експедиторської компанії завжди можна визначити за матрицею виплат. Проведений імітаційний експеримент дозволяє стверджувати, що в більшості випадків оптимальна стратегія експедитора є змішаною (технологічні та комерційні послуги повинні надаватися із заданою ймовірністю при обслуговуванні потоку замовлень від вантажовласників).

Наукова новизна. У роботі вперше проводиться дослідження впливу параметрів потоку замовлень на ймовірності вибору елементарних стратегій.

Практична значимість. Запропонована методологія може бути використана як основний інструмент для підтримки рішень експедиторів при обслуговуванні власників вантажів на ринку автомобільних вантажних перевезень.

Ключові слова: експедирування вантажів, теоретикоігровий підхід, параметри транспортного попиту, потік замовлень

\section{Выбор стратегии обслуживающего предприятия при взаимодействии с грузовладельцами на рынке автомобильного транспорта}

\section{Г. Нугманова ${ }^{1}$, М. Нургалиева ${ }^{2}$, Ж. Жанбиров ${ }^{3}$, B. Наумов ${ }^{4}$, И. Таран}

1 - Казахская Академия транспорта и коммуникации имени М.Тынышпаева, г. Алматы, Республика Казахстан

2 - Казахская автомобильно-дорожная академия имени Л. Гончарова, г. Алматы, Республика Казахстан

3 - Центрально-Азиатский университет, г. Алматы, Республика Казахстан

4 - Краковский политехнический институт имени Т. Костюшко, г. Краков, Республика Польша

2 - Национальный технический университет «Днепровская политехника», г. Днепр, Украина, e-mail: $\underline{\operatorname{taran} 7077 @}$ gmail.com

Цель. Разработка методологии выбора стратегий транспортно-экспедиторских компаний в ситуации взаимодействия с грузовладельцами как заказчиками экспедиторских услуг.

Методика. Теоретико-игровой подход используется для формализации конфликтной ситуации между транс- 
портно-экспедиторской компанией и владельцем груза. Набор услуг, предлагаемых экспедиторами, используется в качестве основы для представления возможных стратегий экспедитора как вектора вероятностей предоставления соответствующих услуг клиенту. Стратегии владельца груза представлены в виде бинарной переменной, которая показывает, будет пользоваться клиент предоставляемыми услугами или нет. Функция выплат для экспедитора определяется как прибыль компании, а функция выплат клиента - в качестве оплаты за предоставление экспедиторских услуг. С целью определения влияния параметров спроса на оптимальные стратегии экспедитора спрос на транспортные услуги представляется как поток заказов, характеризующийся двумя числовыми параметрами - расстоянием доставки и весом партии груза.

Результаты. Проведенные экспериментальные исследования показали, что в результате использования предлагаемой методологии оптимальную стратегию экспедиторской компании всегда можно определить по ма- трице выплат. Проведенный имитационный эксперимент позволяет утверждать, что в большинстве случаев оптимальная стратегия экспедитора является смешанной (технологические и коммерческие услуги должны предоставляться с заданной вероятностью при обслуживании потока заказов от грузовладельцев).

Научная новизна. В работе впервые проводится исследование влияния параметров потока заказов на вероятности выбора элементарных стратегий.

Практическая значимость. Предложенная методология может быть использована как основной инструмент для поддержки решений экспедиторов при обслуживании владельцев грузов на рынке автомобильных грузовых перевозок.

Ключевые слова: экспедирование грузов, теоретикоигровой подход, параметры транспортного спроса, поток заказов

Recommended for publication by V.V.Slesaryev, Doctor of Technical Sciences. The manuscript was submitted 10.07.20. 